\title{
Review Article \\ Current Status and Advances in Quantitative Proteomic Mass Spectrometry
}

\author{
Valerie C. Wasinger, ${ }^{1}$ Ming Zeng, ${ }^{1}$ and Yunki Yau ${ }^{1,2}$ \\ ${ }^{1}$ Bioanalytical Mass Spectrometry Facility, Mark Wainwright Analytical Centre, The University of New South Wales, \\ Sydney, NSW 2052, Australia \\ ${ }^{2}$ Department of Gastroenterology and Liver Services, Concord Repatriation General Hospital, Sydeny, NSW 2139, Australia
}

Correspondence should be addressed to Valerie C. Wasinger; v.wasinger@unsw.edu.au

Received 14 October 2012; Revised 16 January 2013; Accepted 21 January 2013

Academic Editor: Bomie Han

Copyright ( 2013 Valerie C. Wasinger et al. This is an open access article distributed under the Creative Commons Attribution License, which permits unrestricted use, distribution, and reproduction in any medium, provided the original work is properly cited.

\begin{abstract}
The accurate quantitation of proteins and peptides in complex biological systems is one of the most challenging areas of proteomics. Mass spectrometry-based approaches have forged significant in-roads allowing accurate and sensitive quantitation and the ability to multiplex vastly complex samples through the application of robust bioinformatic tools. These relative and absolute quantitative measures using label-free, tags, or stable isotope labelling have their own strengths and limitations. The continuous development of these methods is vital for increasing reproducibility in the rapidly expanding application of quantitative proteomics in biomarker discovery and validation. This paper provides a critical overview of the primary mass spectrometry-based quantitative approaches and the current status of quantitative proteomics in biomedical research.
\end{abstract}

\section{Introduction}

Quantification in a proteomics setting relies on the ability to detect small changes in protein and peptide abundance in response to an altered state [1]. Differential analysis is generated from LC-MS experiments and can be carried out using both label and label-free approaches. For trace amounts of proteins within complex proteomes such as plasma, tears, and urine, no singular technique should be used as a standalone guarantee of quantitative precision without hypothesisdriven, targeted approaches. Enrichment and fractionation of specific classes of protein is beneficial during the discovery phase of a project, but because these methods can involve numerous steps, they can become a limiting factor for large scale validation. The variability introduced by multiple methods prior to quantitative mass spectrometry should be assessed, and it is paramount that protein measurements reflect the authentic concentration in the original sample. The development of methods for accurate protein quantitation is one of the most challenging areas of proteomics.

Quantitative proteomics comes in two forms: absolute and relative. Relative quantitation compares the levels of a specific protein in different samples with results being expressed as a relative fold change of protein abundance [2]. Absolute quantitation is the determination of the exact amount or mass concentration of a protein, for example, in units of $\mathrm{ng} / \mathrm{mL}$ of a plasma biomarker.

Traditional proteomic quantitation approaches rely on high-resolution protein separation by $2 \mathrm{D}$ gels. The use of dyes, fluorophores, or radioactivity to label proteins allows visualization of spots/bands with differential intensities $[3,4]$. These methods facilitate relative abundance comparison but require many replicates and intensive image analysis that can often be quite user subjective. The simplicity of mass spectrometry-based approaches addresses issues of reproducibility [5] and poor representation of low-abundance [6], low-mass, and basic proteins $[7,8]$, as well as the need for the postdifferential identification by MS [3] as it is inherent in the separation methods. MS-based methods have also come into prominence compared to traditional antibody-based methods due to their higher specificity, good reproducibility and precision, and ability to rapidly analyse hundreds of peptide transitions in one MRM assay [9]. Pragmatically, the course of a biomarker project sees a number of quantitative 


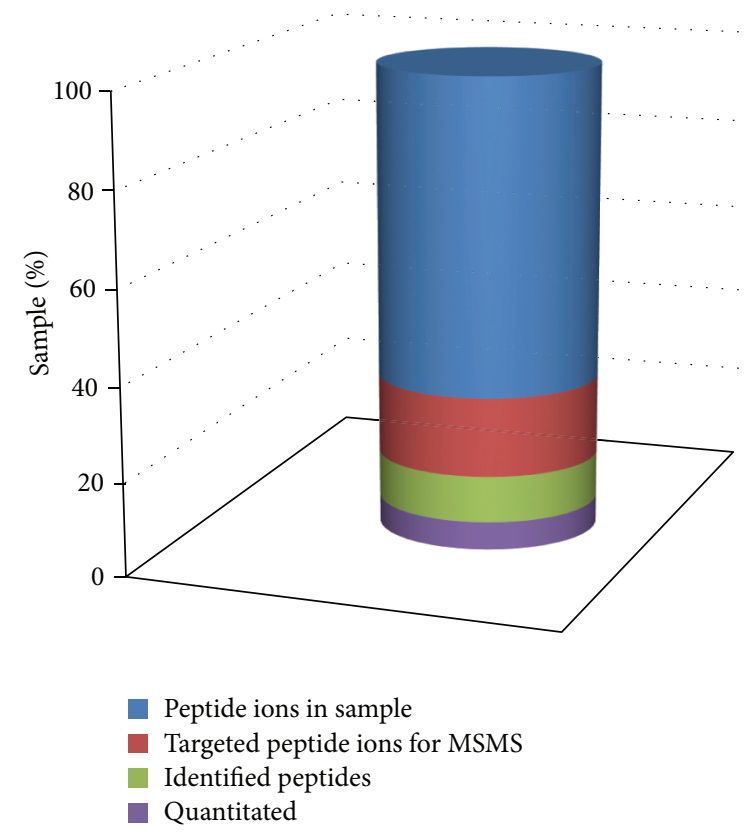

FIGURE 1: Relationship between the peptide ion content and the difficulty in obtaining sufficient MSMS information to both identify and also quantitate those peptides. Adapted from Michalski et al. [10] and Liu et al. [11].

techniques used from discovery-driven low-cost methods such as relative and label-free quantitation to hypothesisdriven quantitation using synthetic standards with complimentary analysis of trends by alternative techniques such as ELISA or Western blot. Here, we provide a critical overview of the main MS-based quantitation approaches and outline the advances and challenges of applying these techniques in protein biomarker discovery and validation.

\section{Quantitative Proteomics in Biomarker Discovery}

The ultimate aim of biomarker discovery is to develop a simple differential test to be used as a clinical evaluation tool. This requires a lengthy and difficult process which involves candidate discovery, verification, validation, and translation to clinical laboratory use $[12,13]$. Current discovery studies aim to detect disease-specific markers by analysing and comparing healthy controls and disease-affected subjects [14], and despite the discovery of increasing numbers of potential markers, few have progressed to clinical practice $[15,16]$. Much of this dilemma is a reflection of the challenges associated with linking bench to clinic outcomes and providing basic researchers with the opportunity to finance and progress their science past the validation phase [12, 17]. The development of targeted, quantitative approaches that provide accurate and statistically reliable quantitative outcomes for multisite studies may provide a critical bridge to establishing validity of individual or panels of biomarkers.

A challenge facing biomarker development is the sheer complexity and range of concentrations within the human proteome $[12,16]$. Human plasma is estimated to contain more than 10,000 core proteins [35], of which only small fractions are effectively characterized with current technology [36]. Proteins in plasma have a $10^{12}$-fold concentration range, from millimolar for albumin, down to attomolar ranges, and further for cytokines [35] and other proteins, hormones, and peptides. This greatly exceeds the ability of current proteomic approaches, which have linearity over $\sim 3$ orders of magnitude [16].

Disease-specific proteins, including low-mass peptides, can be low in abundance and difficult to detect amongst a diverse "sea" of proteins [37]. Combined with the immense extent of human and disease variation and the challenges facing the development of sensitive and specific differentiators, developing these technologies to the clinic is a formidable task. Discovery phase quantitative approaches entail the differentiation of as many peptides as possible (rather than the identification of all proteins) from LC-MS experiments and is highly dependent on scan speed, sensitivity, and ability to isolate precursor ions for selection to MS/MS [10]. Figure 1 shows the relationship between peptide ions and quantitation and is adapted from Michalski et al. [10] and Liu et al. [11]. This figure demonstrates the gap between peptide content and ability to quantitate those peptides and proteins comprehensively to provide quantitative coverage. As instruments improve in these areas, there will be an associated increase in depth of coverage and accuracy which is required to discern the very small changes in abundance, peptide modifications, and mass differences that delineate a disease type or process. For targeted approaches, the use of high-resolution instruments has the advantage of relying on the mass accuracy to provide fewer transitions and therefore being able to simultaneously monitor more peptides within the one scheduled experiment. This should assist the reliability and precision of targeted assays to unambiguously identify the target peptide and avoid interfering transitions particularly in complex biological matrices [38]. Indeed, there is a growing consensus that panels of multiple biomarkers are more likely to achieve adequate clinical sensitivity and specificity $[12,37,39]$.

There are a number of novel techniques that allow for the fractionation, depletion, enrichment, and equalisation of complex samples to assist in improving the proteome coverage and number of peptide ions targeted for MS/MS within an instrument's detection range. Fractionation techniques can be applied to cut samples into subgroups of fewer proteins [15] and are most commonly in the form of (gel) electrophoresis and liquid chromatography (LC), techniques which exploit a variety of physicochemical properties of proteins to fractionate proteomes [7]. To reduce protein concentration variability, high-abundance proteins such as albumin can be removed from plasma samples through immunodepletion. There is, however, a risk of codepletion of potentially significant biomarkers due to nonspecific binding or loss of biomarkers bound to higher-abundance carrier proteins [40-42]. These techniques in combination effectively allow the detection of trace proteins $[7,15,16]$. However, any additional manipulation during the sample processing 


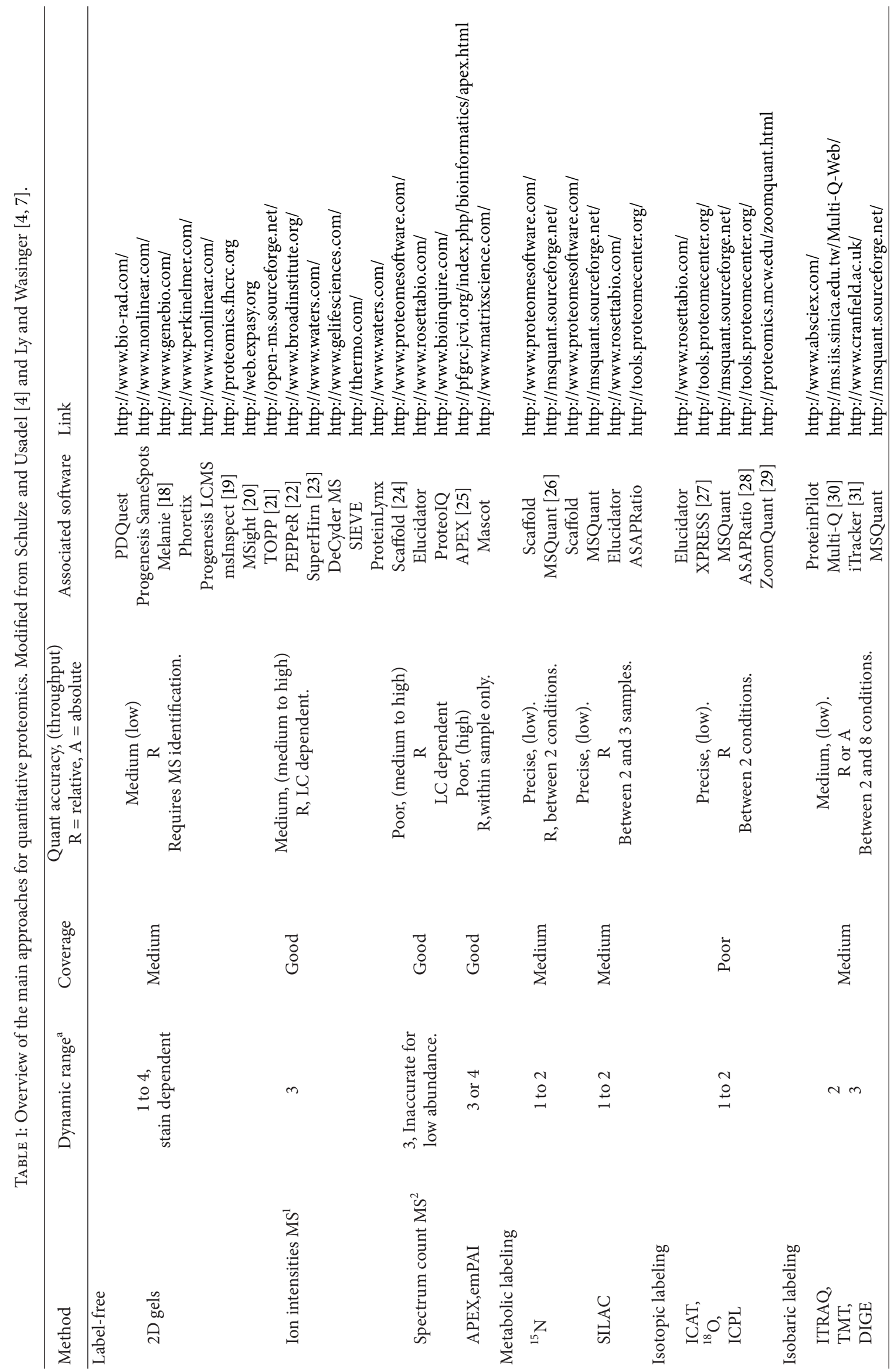




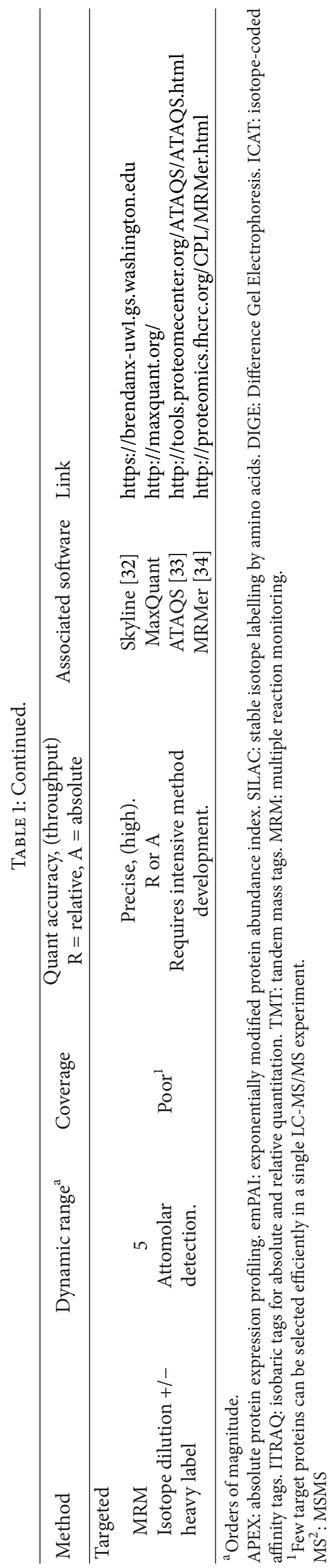


can introduce preanalytical variables that cause changes in quantitative peptide amounts [9]. While the previous techniques can improve discovery of trace levels of candidate protein biomarkers, extensive validation and standardization of these steps will be required before they can be used for direct clinical applications $[9,43]$.

Data analysis is yet another significant challenge associated with MS-based proteomics. With the enormous volumes of proteomic data generated, expert manual analysis would be inconsistent and unfeasible [44]. Thus, bioinformatics tools are crucial in the determination of which proteins and peptides emerge as candidate biomarkers from discovery studies and the interpretation of quantitative data $[9,45]$. There is a need for sophisticated yet transparent computational methods and algorithms to allow for consistent analysis and interpretation of proteomic data using statistical principles [45]. The development and validation of such tools is a critical part in the process of developing quality standards for MS experiments and, hence, generating reproducible and accurate data.

\section{Strengths and Limitations of Mass Spectrometry-Based Quantitative Approaches}

Protein mass spectrometry is not inherently quantitative. There are many reasons as to why the amount of analyte compared to the MS signal intensity does not always show a linear relationship [3, 44]. Because of this, accurate comparisons between two samples must be based on the same individual peptide in LC-MS/MS experiments conducted under the same conditions [4], particularly for absolute quantitation. Table 1 presents an overview of the technical parameters of the main quantitative approaches, their strengths and limitations.

3.1. Label-Free Approaches. Two widely used label-free quantitative methods are spectral counting and peptide peak intensity measurement. Spectral counting requires proteins to have sufficient peptides (both in number and abundance) to trigger MS/MS data for quantification and identification. The approach is based on the observation that more abundant proteins will produce more MS/MS spectra than less abundant proteins, and abundant peptides are sampled more often in fragment ion scans than are low abundance peptides. Relative quantitation by spectral count thus involves comparing the number of identified spectra from the same protein between different samples [54]. Spectral counting is a protein-centric approach that is less reliable for trace and/or low mass proteins; and less responsive toward small changes in response ( $<2$ orders of magnitude) $[11,55]$, favoring higher abundance "average" proteins [2], while lower identification rates for proteins with low sequence coverage and nontryptic or fewer peptides are a consequence of the methods used for identification as much as the dynamic range of the sample and the limited duty cycle of the MS instrument [56]. This approach has been modified into forms such as the exponentially modified protein abundance index [57] and absolute protein expression profiling [58].

Relative quantitation using peptide peak intensity measurements involves comparing the MS peptide ion intensities belonging to a given protein [59]. The ion chromatograms for every peptide are extracted from an LC-MS run, and their peak areas are integrated over the chromatographic time scale. These values can be compared to respective values in other experiments for relative quantitation, and only the same ion species can be compared between different samples. Hence, this approach requires multiple replicates and correlation of retention time with $\mathrm{m} / \mathrm{z}$ ion features and charge state to avoid discrepancy in matching common ions detected in each run. The coverage of common ions between different samples is strongly dependent on sample preparation and can be severely affected by column conditions, instrument sensitivity, and calibration. These variables are pronounced when running long-term projects where analysis is carried out over weeks to months and can introduce approximately $40 \%$ discrepancy at the peptide level [4]. Label-free techniques have been performed in many studies and are promising alternatives to stable isotope labeling. They are fast, easy to perform, and inexpensive, and they allow higher dynamic range [3]. Furthermore, any soluble biological material can be used, and unlimited numbers of samples can be compared [4].

3.2. Stable Isotope Labelling. Stable isotope labelling techniques are based on the introduction of a differential mass tag which affects only the mass of a protein or peptide without changing the chemical properties during chromatography or MS [2]. Relative or absolute quantitation can be achieved by using MS to compare the abundance of a labeled "heavy" (known concentration) against the endogenous "light" isoforms [60]. Stable isotope labels are introduced metabolically or chemically at either the protein or peptide level during sample preparation.

Metabolic labelling involves the introduction of stable isotopes to whole cells through the growth medium, which enables the labels to be incorporated during normal cell growth and division [61]. Differently labelled samples can be pooled together for subsequent preparation which avoids variability of sample preparation. However, this method is not applicable to samples that are not metabolically active such as plasma [2]. While the original ${ }^{15} \mathrm{~N}$ labelling can only compare two samples in one experiment, high-throughput quantitation was developed in the form of stable isotope labelling by amino acids (SILAC) [62]. SILAC incorporates heavy and light forms of arginine or lysine in vivo and also combines light and heavy samples prior to sample preparation to significantly reduce sample handling and thus quantitative errors, allowing very small changes in protein levels as well as protein modifications to be detected.

In chemical labelling, the isotope label is introduced to proteins or peptides by a chemical reaction, such as with isotope-coded affinity tags (ICAT) [63] and isotope-coded protein labels (ICPL) [64]. ICAT labels specifically bind to cysteine, a relatively rare amino acid, which effectively 
TABLE 2: Recent quantitative MS-based studies involving human samples.

\begin{tabular}{|c|c|c|c|c|}
\hline Authors/year & Specimen & $\begin{array}{l}\text { Quantitative } \\
\text { approach }\end{array}$ & $\begin{array}{c}\text { Sample } \\
\text { preparation }\end{array}$ & Outcomes \\
\hline Yang et al. 2011 [46] & $\begin{array}{l}\text { Urine } \\
54 \text { bladder cancer patients, } \\
46 \text { controls }\end{array}$ & $\begin{array}{l}\text { Label-free- } \\
\text { spectral } \\
\text { count }\end{array}$ & NIL & $\begin{array}{l}\text { Quantified } 265 \text { glycoproteins. } \\
\text { alpha-1-antitrypsin, } 74 \% \text { sensitivity and } 80 \% \\
\text { specificity for bladder cancer patients. }\end{array}$ \\
\hline $\begin{array}{l}\text { Quintana et al. } \\
2009 \text { [47] }\end{array}$ & $\begin{array}{l}\text { Urine } \\
39 \text { patients kidney chronic } \\
\text { allograft dysfunction, } 32 \\
\text { controls }\end{array}$ & $\begin{array}{l}\text { Label-free-peak } \\
\text { peptide intensity }\end{array}$ & $\begin{array}{l}\text { SCX using } \\
\text { magnetic beads }\end{array}$ & $\begin{array}{l}\text { Peptides from uromodulin and kininogen } \\
\text { significantly elevated in control compared to } \\
\text { CAD patients. }\end{array}$ \\
\hline $\begin{array}{l}\text { Hanas et al. } 2008 \\
{[48]}\end{array}$ & $\begin{array}{l}\text { Serum } \\
13 \text { pancreatic } \\
\text { adenocarcinoma patients, } \\
12 \text { healthy controls }\end{array}$ & $\begin{array}{l}\text { Label-free-peak } \\
\text { peptide intensity }\end{array}$ & NIL & $\begin{array}{l}\text { Quantified } 20 \text { low-mass serum peaks. } \\
\text { Bootstrap analysis showed peaks could } \\
\text { differentiate cancer from control sera with } \\
\text { 95\% accuracy. }\end{array}$ \\
\hline Xue et al. 2010 [49] & $\begin{array}{l}\text { Cell lysates } \\
\text { Primary and lymph node } \\
\text { metastatic cell lines. } 1 \\
\text { patient. }\end{array}$ & $\begin{array}{l}\text { Label-free-peak } \\
\text { peptide intensity }\end{array}$ & NIL & $\begin{array}{l}145 \text { differential proteins. Western blot and } \\
\text { ROC curve analysis confirmed that } 2 \\
\text { specific proteins could predict colorectal } \\
\text { cancer metastasis. }\end{array}$ \\
\hline $\begin{array}{l}\text { Besson et al. } 2011 \\
{[50]}\end{array}$ & $\begin{array}{l}\text { Colorectal cancer tissue } \\
28 \text { colorectal frozen tissue } \\
\text { samples }\end{array}$ & $\begin{array}{c}\text { Stable isotope } \\
\text { labeling-iTRAQ }\end{array}$ & $\begin{array}{c}\text { Peptide } \\
\text { OFFGEL } \\
\text { fractionation }\end{array}$ & $\begin{array}{l}555 \text { proteins with significant fold change } \\
\text { between different cancer stages. Identified a } \\
\text { candidate with increased abundance in } \\
\text { adenomas and early stage colorectal cancer. }\end{array}$ \\
\hline $\begin{array}{l}\text { Bondar et al. } 2007 \\
\text { [51] }\end{array}$ & $\begin{array}{l}\text { Serum } \\
6 \text { healthy male, } 20 \\
\text { nonmalignant prostate } \\
\text { biopsy patients, } 26 \\
\text { malignant prostate cancer } \\
\text { patients }\end{array}$ & $\begin{array}{l}\text { Stable isotope } \\
\text { labeling }\end{array}$ & NIL & $\begin{array}{l}\text { Higher abundance of } \mathrm{Zn}-\alpha 2 \text { glycoprotein } \\
(\mathrm{ZAG}) \text { in prostate cancer patients than } \\
\text { nonmalignant prostate disease patients and } \\
\text { healthy controls. }\end{array}$ \\
\hline $\begin{array}{l}\text { Chaerkady et al. } \\
2008 \text { [52] }\end{array}$ & $\begin{array}{l}\text { Liver tissue } \\
55 \text { samples of } \\
\text { hepatocellular carcinoma, } \\
20 \text { samples of adjacent } \\
\text { noncancer tissues }\end{array}$ & $\begin{array}{c}\text { Stable isotope } \\
\text { labeling-iTRAQ }\end{array}$ & SCX & $\begin{array}{l}59 \text { proteins increased in abundant, } 92 \\
\text { proteins were less abundant in HCC } \\
\text { compared to normal tissue. } 12 \text { proteins } \\
\text { further validated using } \\
\text { immunohistochemical labeling. }\end{array}$ \\
\hline $\begin{array}{l}\text { Dayon et al. } 2008 \\
\text { [53] }\end{array}$ & $\begin{array}{l}\text { Cerebrospinal fluid } \\
4 \text { postmortem CSF } \\
\text { patients, } 4 \text { antemortem } \\
\text { CSF from living healthy } \\
\text { controls }\end{array}$ & $\begin{array}{l}\text { Stable isotope } \\
\text { labeling-tandem } \\
\text { mass tag isobaric } \\
\text { labeling }\end{array}$ & $\begin{array}{l}\text { Immunoaffinity } \\
\text { depletion of } 6 \\
\text { most abundant } \\
\text { proteins and } \\
\text { SCX }\end{array}$ & $\begin{array}{l}78 \text { proteins more abundant in postmortem } \\
\text { samples compared to antemortem. }\end{array}$ \\
\hline
\end{tabular}

reduces sample complexity but also limits its use since it cannot track proteins that lack cysteine residues [2]. Another limitation of ICAT is that only two samples can be compared in a single analysis.

The development of isobaric mass tags such as tandem mass tag (TMT) [77] and isobaric tags for relative and absolute quantification (iTRAQ) [78] allows for the comparison of up to eight samples in parallel $[79,80]$. iTRAQ involves the introduction of mass-balanced labels at the level of tryptic peptides which produce labelled peptides of the same total mass that coelute in liquid chromatography. The different mass tags are differentiated by the mass spectrometer only upon peptide fragmentation [81]. Despite having disadvantages such as variability in labelling efficiencies and protein digestion [2], TMT and iTRAQ are favourable for quantitative biomarker discovery due to their ability to multiplex up to eight samples [82]. A summary of some recent projects is demonstrated in Table 2 and shows the variety of techniques applied for quantitation.

3.3. Multiple Reaction Monitoring. Multiple reaction monitoring (MRM) is the main current approach for highly confident protein and peptide quantification. MRM targets specific peptides in complex samples by typically using a triple quadrupole mass spectrometer or hybrid triple quadrupole/linear ion trap mass spectrometer. These instruments have two mass filters that can select a predefined peptide ion and a combination of its specific fragment ions to analyse and monitor over time for accurate quantitation $[2,83]$. Combinations of peptide mass and product ion masses create a unique signature for a particular peptide with 


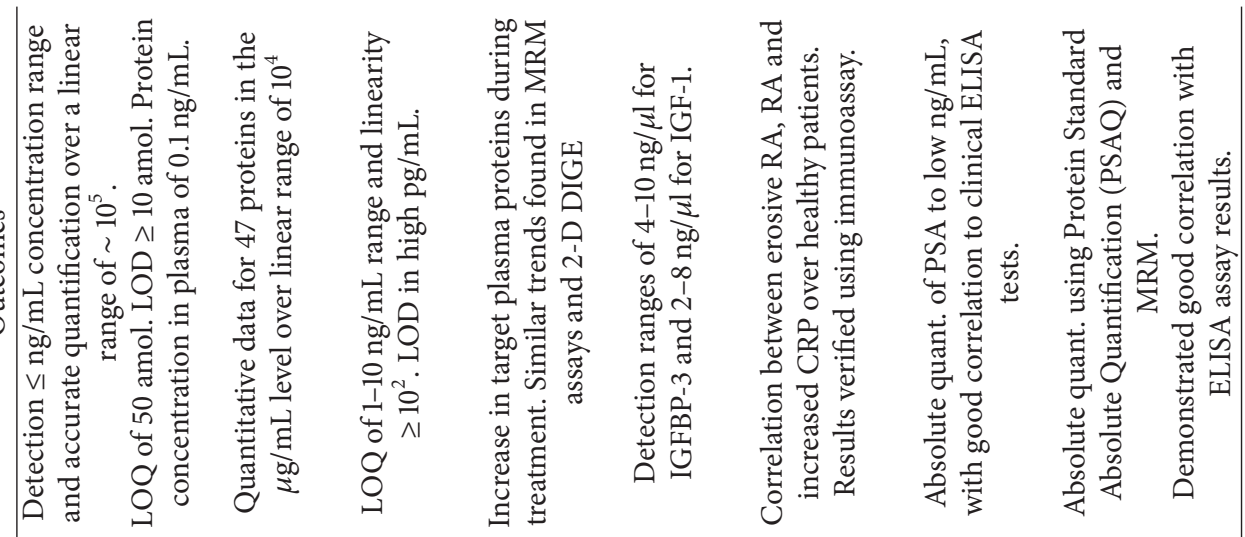

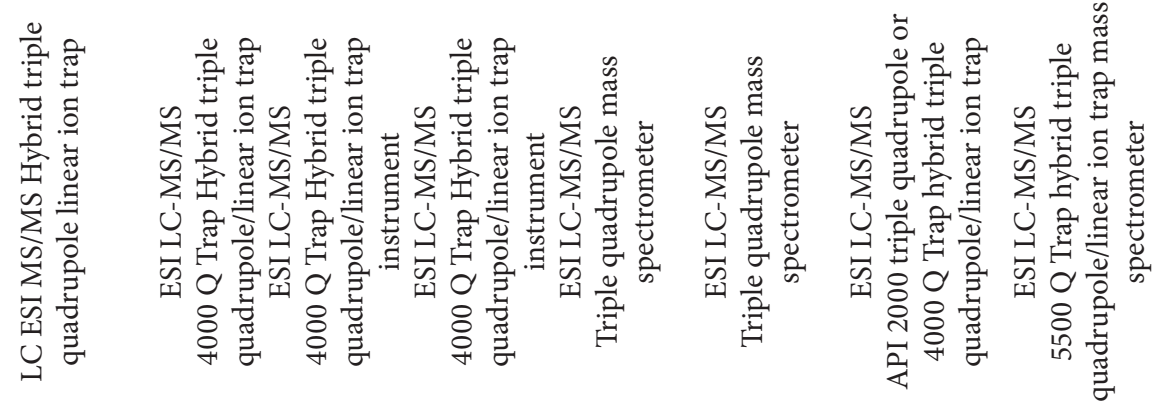

$\frac{7}{0}$

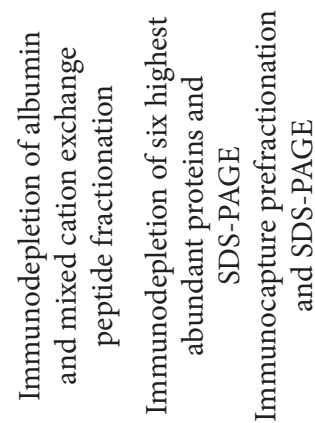

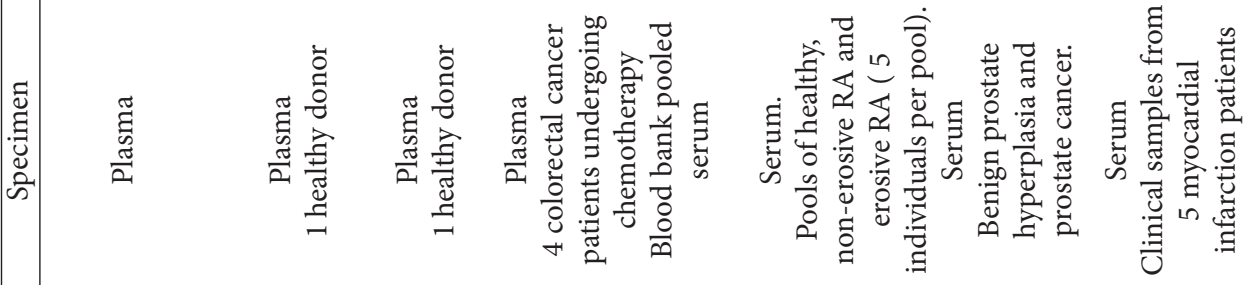

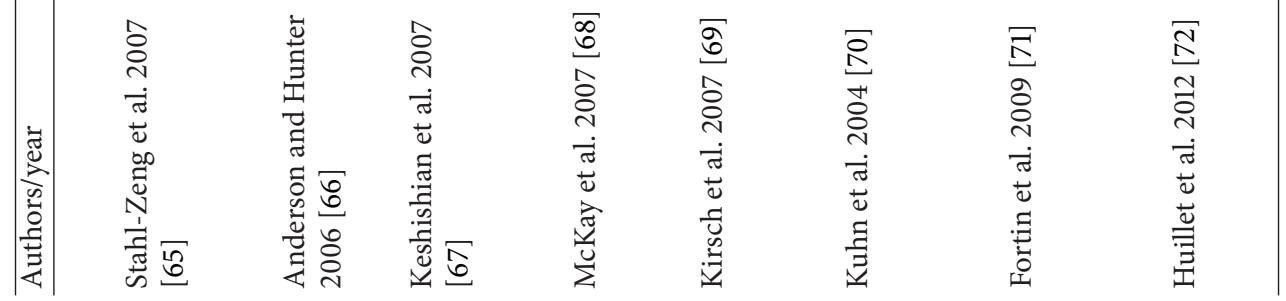




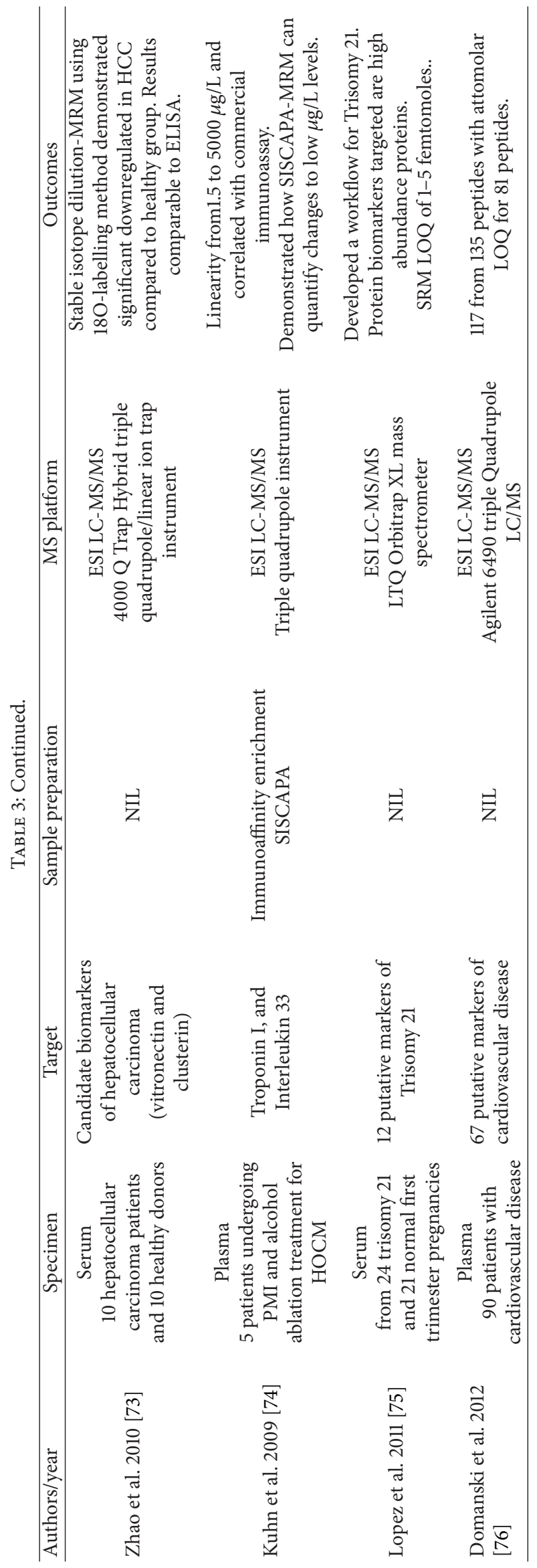


increase in confidence, the more parent and product masses that are detected.

Absolute quantitation can be achieved when MRM is incorporated with isotopically labelled synthetic peptide internal standards, which are designed to be identical to target peptides [84]. For MRM using synthetic internal standards, known concentrations of heavy synthetic peptides are spiked into the sample, and the concentration of the target native peptide can be calculated by measuring the observed MRM response against a standard curve normalised by the internal heavy spike $[3,83]$.

MRM has a greater sensitivity towards low abundance peptides and relatively good quantitative precision compared to other methods discussed [85]. It is capable of detecting attomole concentrations of peptides across a dynamic range of up to $10^{5}[66,86]$. The main challenge of MRM absolute quantitation is the need for suitable internal standards to be synthesized for each target peptide. Furthermore, absolute MRM quantitation only measures the abundance of individual peptides and makes assumptions on the concentration of the whole protein. Therefore, biomarkers detected and quantified using MRM must be validated using multiple peptides from the same protein (challenging for biofluids) and additional technology to confirm the existence of the actual protein [2]. MRM remains peptide-centric for many biomarker studies.

MRM has been used to quantify major plasma proteins and target biomarkers for a range of diseases. Table 3 lists recent studies conducted using plasma and serum for MRMbased approaches with some quantitation achieving attomolar levels of detection of peptides in one of the most complex human samples available. The MRM approach can also be used for relative quantitation without the use of stable isotopes [87]. A recent multi-site study has confirmed the reproducibility and sensitivity of MRM-based quantitation of plasma proteins [88]. MRM therefore holds great potential to be applied as a specific platform for validation of candidate biomarkers in systematic quantitative studies of clinically relevant peptides.

Further instrument developments have taken advantage of the high resolution and mass accuracy of the TOF and orbitrap analysers and combined them with the selectivity of the quad analysers by replacing the third quad with either an orbitrap or a TOF analyser. These high resolution/accurate mass (HR/AM) instruments are addressing the challenge of eliminating cofiltering interfering ions, while taking advantage of the accuracy afforded by these instruments. In experiments similar to MRM called parallel reaction monitoring (PRM), it is possible to detect all product ions of a peptide in parallel rather than just few transitions per peptide. This allows an increased number of peptides to be quantitated in the one experiment. This combination of analysers firstly uses the quadrupole to select a restricted $\mathrm{m} / \mathrm{z}$ range (with broad mass filtering window typically $2-100 \mathrm{Th}$, rather than broad scan of around 700Th), and the MS/MS mode provides further selectivity and accuracy utilizing the orbitrap or TOF analyser to achieve higher resolution and mass accuracy in both MS and MS/MS scanning modes [89]. A reduced mass filter window as low as $0.2 \mathrm{Th}$ allows reliable discrimination of targeted ions and increased sensitivity $<1 \mathrm{ppm}$ and mass accuracy [90]. These instruments are advancing the reliability and accuracy of quantitative proteomics and are just the beginning to a new era in quantitation that will provide inherent quantitative sampling of all peptides and their product ions in highly complex samples.

\section{Postdiscovery Validation Phase Platforms}

The use of multiparametric assays is becoming an increasing necessity in quantitative studies to overcome a variety of challenges associated with properties of the marker and/or the techniques including immobilisation efficiencies, detection, signal-to-noise [91]. Proteomic-based quantitation of potential biomarkers requires further validation using orthogonal techniques. This is required for both verification as much as for the routine measurement in clinical investigations $[12,13]$. The gold standard for validation experiments is by enzyme-linked immunosorbent assays (ELISA). However, alternative techniques such as Western blot, fluorescent bead, chip immunoassay arrays, or Surface Plasmon Resonance (SPR) are also commonly used [91, 92]. Validation by any of these techniques is to complement the onerous requirements for clinical assays: high-throughput, high measurement precision (coefficients of variation of less than 10\%) and sufficient sensitivity [92]. The recent developments in multiplexed protein immunoassays such as lateral flow immunoassays and miniaturized microassays [93] hold great promise in advancing panels of biomarkers developed from MS-based proteomics research towards clinical applications. In addition to these orthogonal approaches, parallel validation techniques involving Stable Isotope Standards and Capture by Antipeptide Antibodies (SISCAPA) [94] may also be beneficial.

\section{Conclusion}

Quantitative proteomic analysis has been a point of discussion for the last four decades, with comparative and once limited MS-based techniques heralding the advances that would forge the necessary connection between the dynamic biology of a system and its quantitative proteomic content. The major advances in quantitative MS proteomics have been exceptionally demonstrated over the last decade with the introduction of compatible and reliable label and label-free techniques. These advances now require further developments in bioinformatics and downstream validation, technologies that are required to make sense of complex data and enable researchers to infer more meaningful data that will transform into clinical benefit for years to come.

\section{References}

[1] S. E. Ong and M. Mann, "Mass spectrometry-based proteomics turns quantitative," Nature Chemical Biology, vol. 1, no. 5, pp. 252-262, 2005.

[2] M. H. Elliott, D. S. Smith, C. E. Parker, and C. Borchers, "Current trends in quantitative proteomics," Journal of Mass Spectrometry, vol. 44, no. 12, pp. 1637-1660, 2009. 
[3] M. Bantscheff, M. Schirle, G. Sweetman, J. Rick, and B. Kuster, "Quantitative mass spectrometry in proteomics: a critical review," Analytical and Bioanalytical Chemistry, vol. 389, no. 4, pp. 1017-1031, 2007.

[4] W. X. Schulze and B. Usadel, "Quantitation in massspectrometry-based proteomics," Annual Review of Plant Biology, vol. 61, pp. 491-516, 2010.

[5] K. S. Lilley, A. Razzaq, and P. Dupree, "Two-dimensional gel electrophoresis: recent advances in sample preparation, detection and quantitation," Current Opinion in Chemical Biology, vol. 6, no. 1, pp. 46-50, 2002.

[6] S. P. Gygi, G. L. Corthals, Y. Zhang, Y. Rochon, and R. Aebersold, "Evaluation of two-dimensional gel electrophoresis-based proteome analysis technology," Proceedings of the National Academy of Sciences of the United States of America, vol. 97, no. 17, pp. 9390-9395, 2000.

[7] L. Ly and V. C. Wasinger, "Protein and peptide fractionation, enrichment and depletion: tools for the complex proteome," Proteomics, vol. 11, no. 4, pp. 513-534, 2011.

[8] L. Ly and V. C. Wasinger, "Peptide enrichment and protein fractionation using selective electrophoresis," Proteomics, vol. 8, no. 20, pp. 4197-4208, 2008.

[9] P. Findeisen and M. Neumaier, "Mass spectrometry based proteomics profiling as diagnostic tool in oncology: current status and future perspective," Clinical Chemistry and Laboratory Medicine, vol. 47, no. 6, pp. 666-684, 2009.

[10] A. Michalski, J. Cox, and M. Mann, "More than 100,000 detectable peptide species elute in single shotgun proteomics runs but the majority is inaccessible to data-dependent LCMS/MS," Journal of Proteome Research, vol. 10, no. 4, pp. 17851793, 2011.

[11] H. Liu, R. G. Sadygov, and J. R. Yates III, "A model for random sampling and estimation of relative protein abundance in shotgun proteomics," Analytical Chemistry, vol. 76, no. 14, pp. 4193-4201, 2004.

[12] N. Rifai, M. A. Gillette, and S. A. Carr, "Protein biomarker discovery and validation: the long and uncertain path to clinical utility," Nature Biotechnology, vol. 24, no. 8, pp. 971-983, 2006.

[13] S. Surinova, R. Schiess, R. Hüttenhain, F. Cerciello, B. Wollscheid, and R. Aebersold, "On the development of plasma protein biomarkers," Journal of Proteome Research, vol. 10, no. 1, pp. 5-16, 2011.

[14] R. Schiess, B. Wollscheid, and R. Aebersold, "Targeted proteomic strategy for clinical biomarker discovery," Molecular Oncology, vol. 3, no. 1, pp. 33-44, 2009.

[15] E. Boschetti, M. Chung, and P. G. Righetti, "The quest for biomarkers': are we on the right technical track?" PROTEOMICS-Clinical Applications, vol. 6, no. 1-2, pp. 22-41, 2012.

[16] G. L. Hortin, S. A. Jortani, J. C. Ritchie, R. Valdes, and D. W. Chan, "Proteomics: a new diagnostic frontier," Clinical Chemistry, vol. 52, no. 7, pp. 1218-1222, 2006.

[17] A. Albalat, H. Mischak, and W. Mullen, "Clinical application of urinary proteomics/peptidomics," Expert Review of Proteomics, vol. 8, no. 5, pp. 615-629, 2011.

[18] R. D. Appel, J. R. Vargas, P. M. Palagi, D. Walther, and D. F. Hochstrasser, "Melanie II-a third-generation software package for analysis of two-dimensional electrophoresis images: II. Algorithms," Electrophoresis, vol. 18, no. 15, pp. 2735-2748, 1997.

[19] M. Bellew, M. Coram, M. Fitzgibbon et al., "A suite of algorithms for the comprehensive analysis of complex protein mixtures using high-resolution LC-MS," Bioinformatics, vol. 22, no. 15, pp. 1902-1909, 2006.

[20] P. M. Palagi, D. Walther, M. Quadroni et al., "MSight: an image analysis software for liquid chromatography-mass spectrometry," Proteomics, vol. 5, no. 9, pp. 2381-2384, 2005.

[21] O. Kohlbacher, K. Reinert, C. Gröpl et al., “TOPP—-the OpenMS proteomics pipeline," Bioinformatics, vol. 23, no. 2, pp. e191-e197, 2007.

[22] J. D. Jaffe, D. R. Mani, K. C. Leptos, G. M. Church, M. A. Gillette, and S. A. Carr, "PEPPeR, a platform for experimental proteomic pattern recognition," Molecular and Cellular Proteomics, vol. 5, no. 10, pp. 1927-1941, 2006.

[23] L. N. Mueller, O. Rinner, A. Schmidt et al., "SuperHirn-a novel tool for high resolution LC-MS-based peptide/protein profiling," Proteomics, vol. 7, no. 19, pp. 3470-3480, 2007.

[24] B. C. Searle, "Scaffold: a bioinformatic tool for validating MS/MS-based proteomic studies," Proteomics, vol. 10, no. 6, pp. 1265-1269, 2010

[25] J. C. Braisted, S. Kuntumalla, C. Vogel et al., "The APEX quantitative proteomics tool: generating protein quantitation estimates from LC-MS/MS proteomics results," BMC Bioinformatics, vol. 9, article 529, 2008.

[26] W. X. Schulze and M. Mann, "A novel proteomic screen for peptide-protein interactions," The Journal of Biological Chemistry, vol. 279, no. 11, pp. 10756-10764, 2004.

[27] D. K. Han, J. Eng, H. Zhou, and R. Aebersold, "Quantitative profiling of differentiation-induced microsomal proteins using isotope-coded affinity tags and mass spectrometry," Nature Biotechnology, vol. 19, no. 10, pp. 946-951, 2001.

[28] X. J. Li, H. Zhang, J. A. Ranish, and R. Aebersold, “Automated statistical analysis of protein abundance ratios from data generated by stable-isotope dilution and tandem mass spectrometry," Analytical Chemistry, vol. 75, no. 23, pp. 6648-6657, 2003.

[29] B. D. Halligan, R. Y. Slyper, S. N. Twigger, W. Hicks, M. Olivier, and A. S. Greene, "ZoomQuant: an application for the quantitation of stable isotope labeled peptides," Journal of the American Society for Mass Spectrometry, vol. 16, no. 3, pp. 302306, 2005.

[30] W. T. Lin, W. N. Hung, Y. H. Yian et al., "Multi-Q: a fully automated tool for multiplexed protein quantitation," Journal of Proteome Research, vol. 5, no. 9, pp. 2328-2338, 2006.

[31] I. P. Shadforth, T. P. J. Dunkley, K. S. Lilley, and C. Bessant, "i-Tracker: for quantitative proteomics using iTRAQU゚," $B M C$ Genomics, vol. 6, article 145, 2005.

[32] B. MacLean, D. M. Tomazela, N. Shulman et al., "Skyline: an open source document editor for creating and analyzing targeted proteomics experiments," Bioinformatics, vol. 26, no. 7, Article ID btq054, pp. 966-968, 2010.

[33] J. Cox and M. Mann, "MaxQuant enables high peptide identification rates, individualized p.p.b.-range mass accuracies and proteome-wide protein quantification," Nature Biotechnology, vol. 26, no. 12, pp. 1367-1372, 2008.

[34] D. B. Martin, T. Holzman, D. May et al., "MRMer, an interactive open source and cross-platform system for data extraction and visualization of multiple reaction monitoring experiments," Molecular and Cellular Proteomics, vol. 7, no. 11, pp. 2270-2278, 2008.

[35] N. L. Anderson and N. G. Anderson, "The human plasma proteome: history, character, and diagnostic prospects," Molecular and Cellular Proteomics, vol. 1, no. 11, pp. 845-867, 2002. 
[36] G. S. Omenn, D. J. States, T. W. Blackwell et al., "Challenges in deriving high-confidence protein identifications from data gathered by a HUPO plasma proteome collaborative study," Nature Biotechnology, vol. 24, no. 3, pp. 333-338, 2006.

[37] E. F. Petricoin, C. Belluco, R. P. Araujo, and L. A. Liotta, “The blood peptidome: a higher dimension of information content for cancer biomarker discovery," Nature Reviews Cancer, vol. 6, no. 12, pp. 961-967, 2006.

[38] J. A. Hewel, S. Phanse, J. Liu, N. Bousette, A. Gramolini, and A. Emili, "Targeted protein identification, quantification and reporting for high-resolution nanoflow targeted peptide monitoring," Journal of Proteomics, 2012.

[39] S. M. Hanash, S. J. Pitteri, and V. M. Faca, "Mining the plasma proteome for cancer biomarkers," Nature, vol. 452, no. 7187, pp. 571-579, 2008.

[40] W. C. S. Cho and C. H. K. Cheng, "Oncoproteomics: current trends and future perspectives," Expert Review of Proteomics, vol. 4, no. 3, pp. 401-410, 2007.

[41] J. Granger, J. Siddiqui, S. Copeland, and D. Remick, "Albumin depletion of human plasma also removes low abundance proteins including the cytokines," Proteomics, vol. 5, no. 18, pp. 4713-4718, 2005.

[42] E. Bellei, S. Bergamini, E. Monari et al., "High-abundance proteins depletion for serum proteomic analysis: concomitant removal of non-targeted proteins," Amino Acids, vol. 40, no. 1, pp. 145-156, 2011.

[43] A. J. Rai and F. Vitzthum, "Effects of preanalytical variables on peptide and protein measurements in human serum and plasma: implications for clinical proteomics," Expert Review of Proteomics, vol. 3, no. 4, pp. 409-426, 2006.

[44] R. Aebersold and M. Mann, "Mass spectrometry-based proteomics," Nature, vol. 422, no. 6928, pp. 198-207, 2003.

[45] D. Reker and L. Malmström, "Bioinformatic challenges in targeted proteomics," Journal of Proteome Research, vol. 11, no. 9, pp. 4393-4402, 2012.

[46] N. Yang, S. Feng, K. Shedden et al., "Urinary glycoprotein biomarker discovery for bladder cancer detection using LC/MS-MS and label-free quantification," Clinical Cancer Research, vol. 17, no. 10, pp. 3349-3359, 2011.

[47] L. F. Quintana, J. M. Campistol, M. P. Alcolea, E. BañonManeus, A. Solé-González, and P. R. Cutillas, "Application of label-free quantitative peptidomics for the identification of urinary biomarkers of kidney chronic allograft dysfunction," Molecular and Cellular Proteomics, vol. 8, no. 7, pp. 1658-1673, 2009.

[48] J. S. Hanas, J. R. Hocker, J. Y. Cheung et al., "Biomarker identification in human pancreatic cancer sera," Pancreas, vol. 36, no. 1, pp. 61-69, 2008.

[49] H. Xue, B. Lü, J. Zhang et al., "Identification of serum biomarkers for colorectal cancer metastasis using a differential secretome approach," Journal of Proteome Research, vol. 9, no. 1, pp. 545-555, 2010.

[50] D. Besson, A. H. Pavageau, I. Valo et al., "A quantitative proteomic approach of the different stages of colorectal cancer establishes OLFM4 as a new nonmetastatic tumor marker," Molecular and Cellular Proteomics, vol. 10, no. 12, Article ID M111.009712, 2011.

[51] O. P. Bondar, D. R. Barnidge, E. W. Klee, B. J. Davis, and G. G. Klee, "LC-MS/MS quantification of Zn- $\alpha 2$ glycoprotein: a potential serum biomarker for prostate cancer," Clinical Chemistry, vol. 53, no. 4, pp. 673-678, 2007.
[52] R. Chaerkady, H. C. Harsha, A. Nalli et al., "A quantitative proteomic approach for identification of potential biomarkers in hepatocellular carcinoma," Journal of Proteome Research, vol. 7, no. 10, pp. 4289-4298, 2008.

[53] L. Dayon, A. Hainard, V. Licker et al., "Relative quantification of proteins in human cerebrospinal fluids by MS/MS using 6-plex isobaric tags," Analytical Chemistry, vol. 80, no. 8, pp. 2921-2931, 2008.

[54] M. Wang, J. You, K. G. Bemis, T. J. Tegeler, and D. P. G. Brown, "Label-free mass spectrometry-based protein quantification technologies in proteomic analysis," Briefings in Functional Genomics and Proteomics, vol. 7, no. 5, pp. 329-339, 2008.

[55] W. M. Old, K. Meyer-Arendt, L. Aveline-Wolf et al., "Comparison of label-free methods for quantifying human proteins by shotgun proteomics," Molecular and Cellular Proteomics, vol. 4, no. 10, pp. 1487-1502, 2005.

[56] A. Prakash, B. Piening, J. Whiteaker et al., "Assessing bias in experiment design for large scale mass spectrometry-based quantitative proteomics," Molecular and Cellular Proteomics, vol. 6, no. 10, pp. 1741-1748, 2007.

[57] J. Rappsilber, U. Ryder, A. I. Lamond, and M. Mann, "Largescale proteomic analysis of the human spliceosome," Genome Research, vol. 12, no. 8, pp. 1231-1245, 2002.

[58] E. Xixi, P. Dimitraki, K. Vougas, S. Kossida, G. Lubec, and M. Fountoulakis, "Proteomic analysis of the mouse brain following protein enrichment by preparative electrophoresis," Electrophoresis, vol. 27, no. 7, pp. 1424-1431, 2006.

[59] W. Zhu, J. W. Smith, and C. M. Huang, "Mass spectrometrybased label-free quantitative proteomics," Journal of Biomedicine \& Biotechnology, vol. 2010, Article ID 840518, 6 pages, 2010.

[60] S. E. Ong, L. J. Foster, and M. Mann, "Mass spectrometric-based approaches in quantitative proteomics," Methods, vol. 29, no. 2, pp. 124-130, 2003.

[61] S. Julka and F. Regnier, "Quantification in proteomics through stable isotope coding: a review," Journal of Proteome Research, vol. 3, no. 3, pp. 350-363, 2004.

[62] S. E. Ong, B. Blagoev, I. Kratchmarova et al., "Stable isotope labeling by amino acids in cell culture, SILAC, as a simple and accurate approach to expression proteomics," Molecular and Cellular Proteomics, vol. 1, no. 5, pp. 376-386, 2002.

[63] S. P. Gygi, B. Rist, S. A. Gerber, F. Turecek, M. H. Gelb, and R. Aebersold, "Quantitative analysis of complex protein mixtures using isotope-coded affinity tags," Nature Biotechnology, vol. 17, no. 10, pp. 994-999, 1999.

[64] A. Schmidt, J. Kellermann, and F. Lottspeich, "A novel strategy for quantitative proteomics using isotope-coded protein labels," Proteomics, vol. 5, no. 1, pp. 4-15, 2005.

[65] J. Stahl-Zeng, V. Lange, R. Ossola et al., "High sensitivity detection of plasma proteins by multiple reaction monitoring of N-glycosites," Molecular and Cellular Proteomics, vol. 6, no. 10, pp. 1809-1817, 2007.

[66] L. Anderson and C. L. Hunter, "Quantitative mass spectrometric multiple reaction monitoring assays for major plasma proteins," Molecular and Cellular Proteomics, vol. 5, no. 4, pp. 573-588, 2006

[67] H. Keshishian, T. Addona, M. Burgess, E. Kuhn, and S. A. Carr, "Quantitative, multiplexed assays for low abundance proteins in plasma by targeted mass spectrometry and stable isotope dilution," Molecular and Cellular Proteomics, vol. 6, no. 12, pp. 2212-2229, 2007. 
[68] M. J. McKay, J. Sherman, M. T. Laver, M. S. Baker, S. J. Clarke, and M. P. Molloy, "The development of multiple reaction monitoring assays for liver-derived plasma proteins," PROTEOMICS_Clinical Applications, vol. 1, no. 12, pp. 15701581, 2007.

[69] S. Kirsch, J. Widart, J. Louette, J. F. Focant, and E. De Pauw, "Development of an absolute quantification method targeting growth hormone biomarkers using liquid chromatography coupled to isotope dilution mass spectrometry," Journal of Chromatography A, vol. 1153, no. 1-2, pp. 300-306, 2007.

[70] E. Kuhn, J. Wu, J. Karl, H. Liao, W. Zolg, and B. Guild, "Quantification of C-reactive protein in the serum of patients with rheumatoid arthritis using multiple reaction monitoring mass spectrometry and 13C-labeled peptide standards," Proteomics, vol. 4, no. 4, pp. 1175-1186, 2004.

[71] T. Fortin, A. Salvador, J. P. Charrier et al., "Clinical quantitation of prostate-specific antigen biomarker in the low nanogram/milliliter range by conventional bore liquid chromatography-tandem mass spectrometry (multiple reaction monitoring) coupling and correlation with ELISA tests," Molecular and Cellular Proteomics, vol. 8, no. 5, pp. 1006-1015, 2009.

[72] C. Huillet, A. Adrait, D. Lebert et al., "Accurate quantification of cardiovascular biomarkers in serum using protein standard absolute quantification (PSAQ) and selected reaction monitoring," Molecular and Cellular Proteomics, vol. 11, no. 2, Article ID M111.008235, 2012.

[73] Y. Zhao, W. Jia, W. Sun et al., "Combination of improved ${ }^{18} \mathrm{O}$ incorporation and multiple reaction monitoring: a universal strategy for absolute quantitative verification of serum candidate biomarkers of liver cancer," Journal of Proteome Research, vol. 9, no. 6, pp. 3319-3327, 2010.

[74] E. Kuhn, T. Addona, H. Keshishian et al., "Developing multiplexed assays for troponin I and interleukin-33 in plasma by peptide immunoaffinity enrichment and targeted mass spectrometry," Clinical Chemistry, vol. 55, no. 6, pp. 1108-1117, 2009.

[75] M. Lopez, R. Kuppusamy, D. Sarracino et al., "Mass spectrometric discovery and selective reaction monitoring (SRM) of putative protein biomarker candidates in first trimester trisomy 21 maternal serum," Journal of Proteome Research, vol. 10, no. 1, pp. 133-142, 2011.

[76] D. Domanski, A. J. Percy, J. Yang et al., "MRM-based multiplexed quantitation of 67 putative cardiovascular disease biomarkers in human plasma," Proteomics, vol. 12, no. 8, pp. 1222-1243, 2012.

[77] A. Thompson, J. Schäfer, K. Kuhn et al., “Tandem mass tags: a novel quantification strategy for comparative analysis of complex protein mixtures by MS/MS," Analytical Chemistry, vol. 75, no. 8, pp. 1895-1904, 2003.

[78] P. L. Ross, Y. N. Huang, J. N. Marchese et al., "Multiplexed protein quantitation in Saccharomyces cerevisiae using aminereactive isobaric tagging reagents," Molecular and Cellular Proteomics, vol. 3, no. 12, pp. 1154-1169, 2004.

[79] S. Wiese, K. A. Reidegeld, H. E. Meyer, and B. Warscheid, "Protein labeling by iTRAQ: a new tool for quantitative mass spectrometry in proteome research," Proteomics, vol. 7, no. 3, pp. 340-350, 2007.

[80] K. Aggarwal, L. H. Choe, and K. H. Lee, "Shotgun proteomics using the iTRAQ isobaric tags," Briefings in Functional Genomics and Proteomics, vol. 5, no. 2, pp. 112-120, 2006.
[81] M. Latterich, M. Abramovitz, and B. Leyland-Jones, "Proteomics: new technologies and clinical applications," European Journal of Cancer, vol. 44, no. 18, pp. 2737-2741, 2008.

[82] K. L. Simpson, A. D. Whetton, and C. Dive, "Quantitative mass spectrometry-based techniques for clinical use: biomarker identification and quantification," Journal of Chromatography B, vol. 877, no. 13, pp. 1240-1249, 2009.

[83] V. Lange, P. Picotti, B. Domon, and R. Aebersold, "Selected reaction monitoring for quantitative proteomics: a tutorial," Molecular Systems Biology, vol. 4, no. 1, article 222, 2008.

[84] S. A. Gerber, J. Rush, O. Stemman, M. W. Kirschner, and S. P. Gygi, "Absolute quantification of proteins and phosphoproteins from cell lysates by tandem MS," Proceedings of the National Academy of Sciences of the United States of America, vol. 100, no. 12, pp. 6940-6945, 2003.

[85] W. J. Qian, J. M. Jacobs, T. Liu, D. G. Camp, and R. D. Smith, "Advances and challenges in liquid chromatographymass spectrometry-based proteomics profiling for clinical applications," Molecular and Cellular Proteomics, vol. 5, no. 10, pp. 1727-1744, 2006.

[86] A. Wolf-Yadlin, S. Hautaniemi, D. A. Lauffenburger, and F. M. White, "Multiple reaction monitoring for robust quantitative proteomic analysis of cellular signaling networks," Proceedings of the National Academy of Sciences of the United States of America, vol. 104, no. 14, pp. 5860-5865, 2007.

[87] C. Ludwig, M. Claassen, A. Schmidt, and R. Aebersold, "Estimation of absolute protein quantities of unlabeled samples by selected reaction monitoring mass spectrometry," Molecular and Cellular Proteomics, vol. 11, no. 3, Article ID M111.013987, 2012.

[88] T. A. Addona, S. E. Abbatiello, B. Schilling et al., "Multi-site assessment of the precision and reproducibility of multiple reaction monitoring-based measurements of proteins in plasma," Nature Biotechnology, vol. 27, no. 7, pp. 633-641, 2009.

[89] S. Gallien, E. Duriez, C. Crone, M. Kellmann, T. Moehring, and B. Domon, "Targeted proteomic quantification on quadrupoleorbitrap mass spectrometer," Molecular and Cellular Proteomics, vol. 11, no. 12, pp. 1709-1723, 2012.

[90] A. C. Peterson, J. D. Russell, D. J. Bailey, M. S. Westphall, and J. J. Coon, "Parallel reaction monitoring for high resolution and high mass accuracy quantitative, targeted proteomics," Molecular and Cellular Proteomics, vol. 11, no. 11, pp. 1475-1488, 2012.

[91] K. Köhler and H. Seitz, "Validation processes of protein biomarkers in serum-a cross platform comparison," Sensors, vol. 12, no. 9, pp. 12710-12728, 2012.

[92] S. F. Kingsmore, "Multiplexed protein measurement: technologies and applications of protein and antibody arrays," Nature Reviews Drug Discovery, vol. 5, no. 4, pp. 310-321, 2006.

[93] A. A. Ellington, I. J. Kullo, K. R. Bailey, and G. G. Klee, "Antibody-based protein multiplex platforms: technical and operational challenges," Clinical Chemistry, vol. 56, no. 2, pp. 186-193, 2010.

[94] N. L. Anderson, N. G. Anderson, L. R. Haines, D. B. Hardie, R. W. Olafson, and T. W. Pearson, "Mass spectrometric quantitation of peptides and proteins using stable isotope standards and capture by anti-peptide antibodies (SISCAPA)," Journal of Proteome Research, vol. 3, no. 2, pp. 235-244, 2004. 

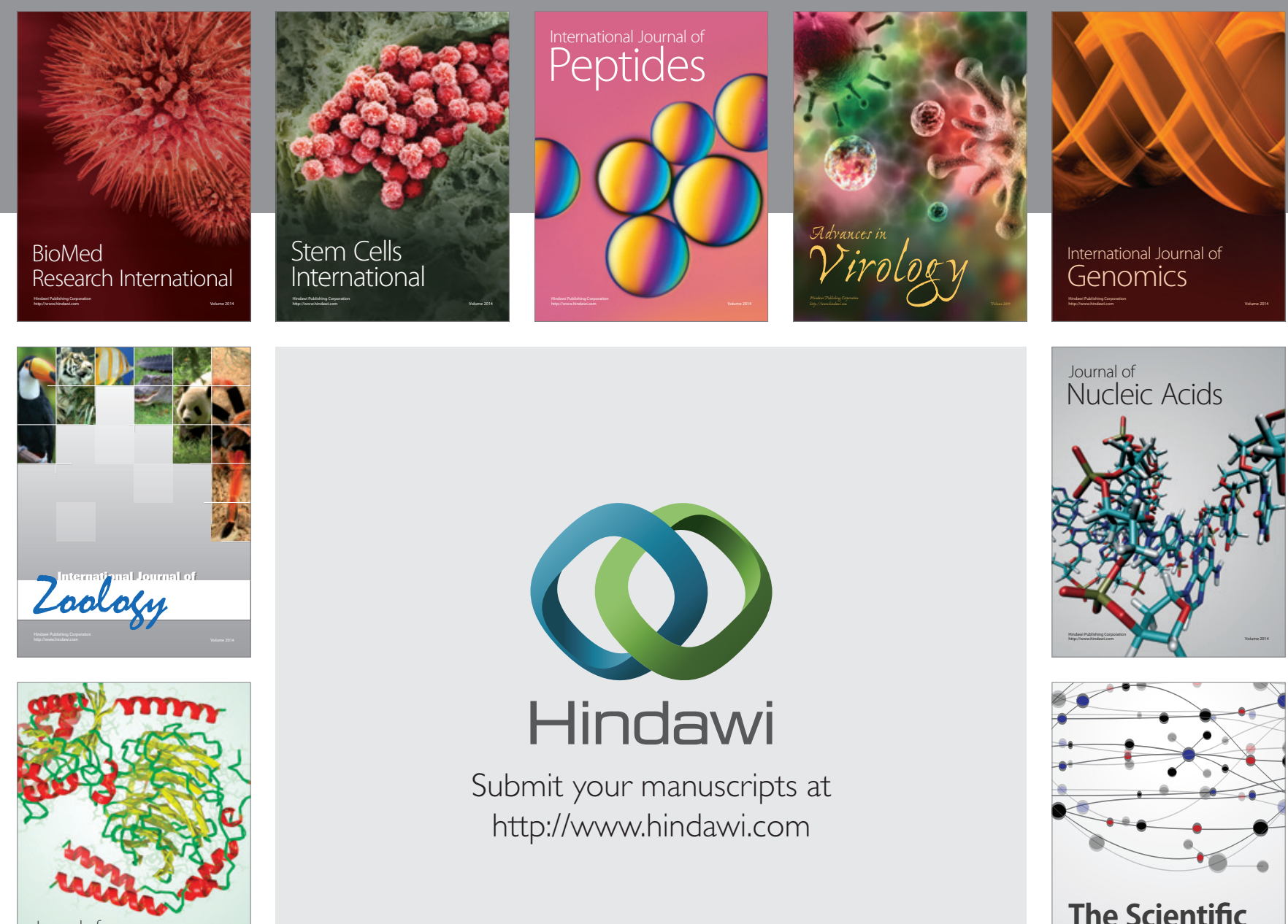

Submit your manuscripts at

http://www.hindawi.com

Journal of
Signal Transduction
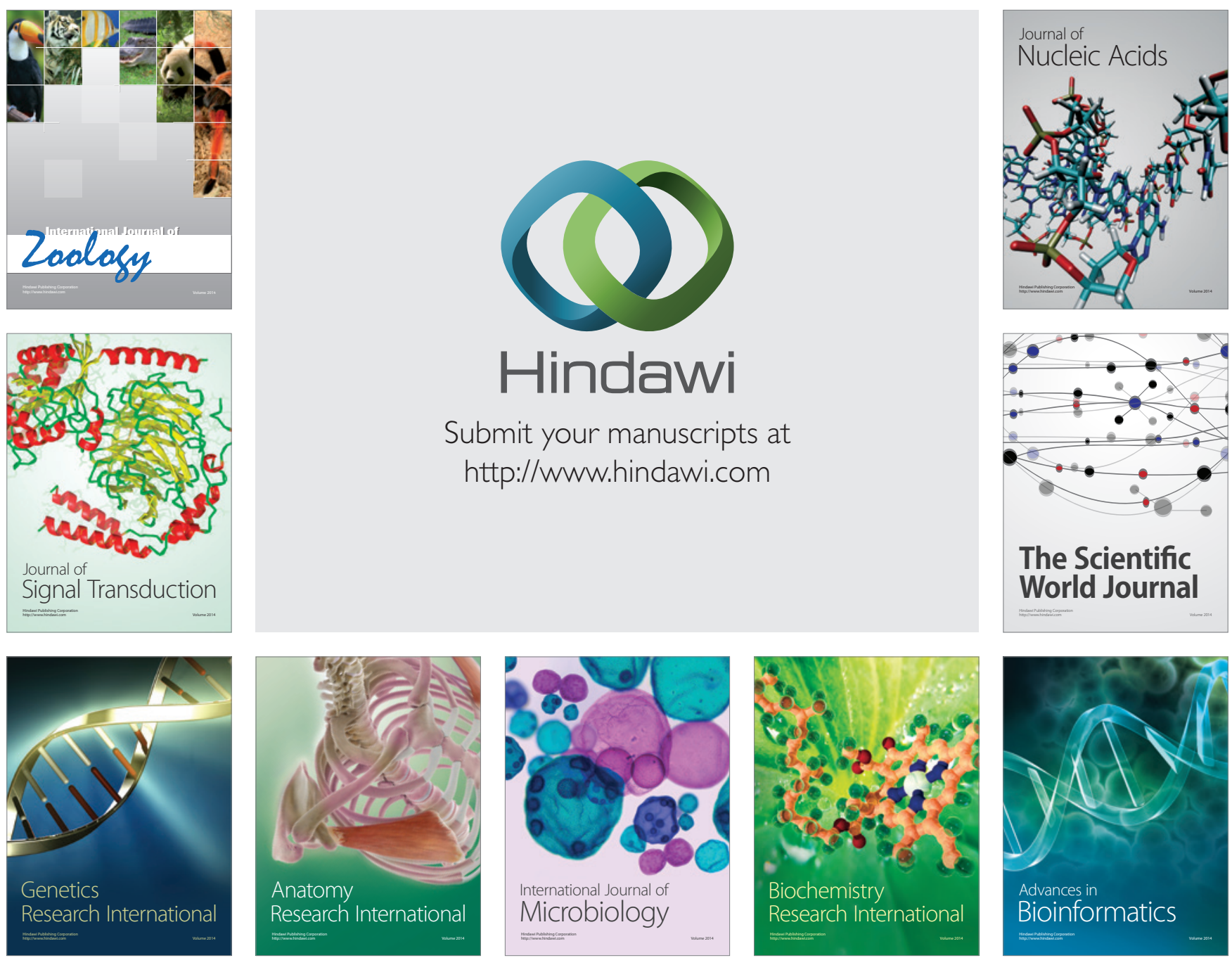

The Scientific World Journal
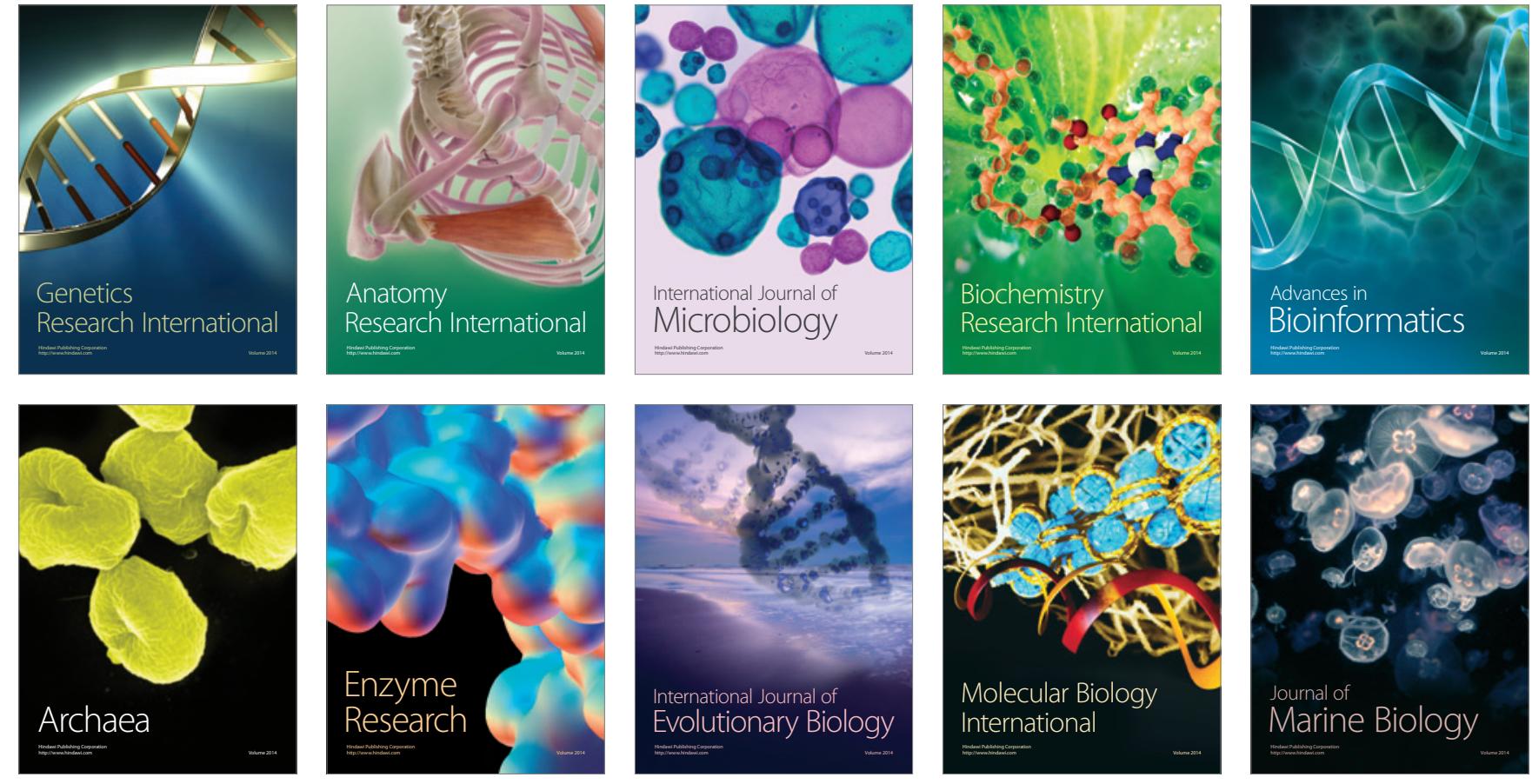